general, we are given an admirable, if condensed, summary of the subjects dealt with, though in places a critic may pick out a carelessly written sentence, e.g. the dictum (p. 2) that "no substance can at once possess both vectorial and scalar properties." Any work treating of a new and rapidly developing subject must inevitably contain statements which have become obsolete even before their publication, and in a second edition Dr. Elsden will doubtless revise such passages as those relating to quartz and tridymite (p. I04), amphibole and pyroxene (pp. II I et seq.), and lime-olivine (p. 203). Meanwhile, the book, in addition to its intrinsic value, will attain the author's expressed desire to stimulate interest in this important branch of geology.

A. $\mathrm{H}$.

\section{THE MAKING OF GARDENS.}

Hardy Plants for Cottage Gardens. By Helen R. Albee. Pp. vi+309. (New York: Henry Holt and Company.) Price i.6o dollars net.

THIS volume forms part of the American Nature Series: Group iv., Working with Nature. From the title one would expect to find the work severely technical and somewhat dull-_."dull and useful as work clothes and garden boots," as the author herself describes a certain chapter. But the title, though appropriate for a section of the work, is to some extent inadequate, as the book proves to be an essay on garden-making, written in a light and racy style, reminiscent of Charles Dudley Warner's delightful "My Summer in a Garden."

The greater part of the volume is devoted to a detailed account of the evolution of the author's garden, through the various stages "In the beginning," "An incipient garden," "The garden grows," "My ambition grows," and gliding on bv easy transition to such apparently inconsequent subjects as "the vices of plants" and "some gardeners I have known." But though the author in her narrative of the six years' labour involved in the formation of her garden ranges over a wide field of horticultural economy, the sequence is so easy and natural that the reader's interest is not allowed to flag, and it is with regret that one reaches the classified lists which occupy the last 122 pages of the book.

These lists are conventional, and call for little comment. The method of classification adopted, though at first sight somewhat complex, will probably facilitate reference. The lists comprise a selection of shrubs and perennials, with descriptions and brief cultural directions, and are arranged primarily under colour headings, and, secondarily, according to the months in which the plants flower. A selection of annuals arranged according to the same system follows. It may be pointed out that this might have been incorporated with the shrubs and perennials, thereby avoiding a somewhat bewildering multiplicity of headings. The work is profusely illustrated with views of the author's garden at various stages, and a copious index is provided.

The author has not laid down hard and fast rules for the formation of a flower garden. Nor does she desire that others should follow slavishly the lines on NO. 2 I43, VOL. 85$]$ which she has worked. "It is not well to imitate another's work, but to follow where your own conditions lead." Her experiences are related with a view to stimulating others who may have the opportunity and the desire to create a garden after their own heart, but who may lack the courage to break away from the conventional or who are diffident as to their ability to shape a new course for themselves. isy such the book will be found rich in suggestion. Above all is it a plea for the free play of imagination in the garden.

"No one should have a garden which grows nothing but flowers, and yields no other recompense to the gardener except successful plants. Over, beyond, and above must hover the spirit of poetry, of wonder, of mystery; otherwise there comes a day of disillusion when you awaken to the weariness, anxiety, and watchfulness, and begin to measure the reward. You need a larger insight, something that connects your efforts with the universal in nature, the ideal, the soul of things. Into this you may lift the garden, and at once drop the tired body and soiled hands, and the whole material aspect of labour."

\section{PHARMACEUTICAL PRACTICE.}

The Extra Pharmacopoei: of Martindale and Westcott. Revised by Dr. W. Harrison Martindale and W. Wynn Westcott. Fourteenth edition. Pp. xxvii + 1054. Price I2s. net. With supplement, Organic Analysis Chart. By W. H. Martindale. Pp. 8o. (London: H. K. Lewis, ıgıo.) Price $3 s$. $6 d$. net.

THIS handbook, which is so familiar to medical and pharmaceutical practitioners, appears in its fourteenth edition in a slightly altered form, the size of the pages having been enlarged so as to allow if the inclusion of new matter without increasing the thickness of the book. It will, however, still fit comfortably in the coat pocket, which is not an altogether unimportant advantage.

The two years that have elapsed since the appearance of the thirteenth edition have yielded an unusual amount of valuable therapeutic literature, a judicious condensation of which forms, for the most part, the new matter of the fourteenth edition. There are new chapters upon lactic acid bacilli therapy, organic arsenic compounds, the electrical introduction into the tissues of medicaments in the ionised condition, and radiology. In addition, the most recent information relating to a number of new pharmaceutical and chemical preparations is incorporated, and recent progress in vaccine therapy, cancer research, trypanosomiasis, and the treatment of tuberculosis is noted. The results of the chemical and bacteriological inquiry into the value of disinfectants undertaken by The Lancet commission are summarised.

The above is a brief outline of the extent of the revision in so far as it is of direct interest to the medical practitioner, but it may be added that throughout the book there is evidence that the authors have scrupulously followed the medical literature of the past two years. Alterations which enhance the usefulness of the book to pharmacists are by no means inconspicuous. Details are given of about a hundred more patent or proprietary medicines than in the last 